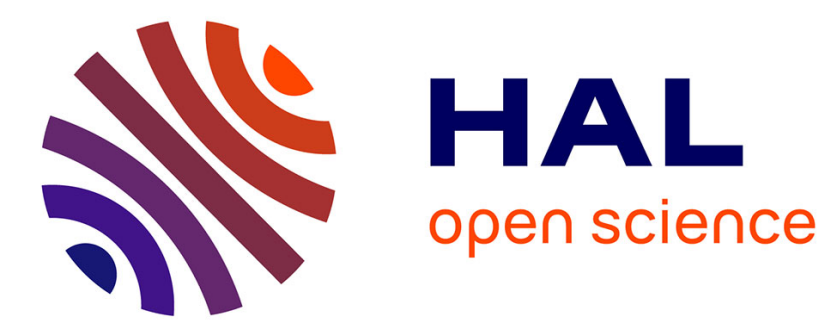

\title{
Lower Abstraction Level of TRIZ Inventive Principles Improves Ideation Productivity of Engineering Students
}

\author{
Pavel Livotov, Arun Prasad Chandra Sekaran, - Mas'udah
}

\section{To cite this version:}

Pavel Livotov, Arun Prasad Chandra Sekaran, - Mas'udah. Lower Abstraction Level of TRIZ Inventive Principles Improves Ideation Productivity of Engineering Students. 19th International TRIZ Future Conference (TFC), Oct 2019, Marrakesh, Morocco. pp.526-538, 10.1007/978-3-030-32497-1_41 . hal02905548

\section{HAL Id: hal-02905548 \\ https://hal.inria.fr/hal-02905548}

Submitted on 23 Jul 2020

HAL is a multi-disciplinary open access archive for the deposit and dissemination of scientific research documents, whether they are published or not. The documents may come from teaching and research institutions in France or abroad, or from public or private research centers.
L'archive ouverte pluridisciplinaire HAL, est destinée au dépôt et à la diffusion de documents scientifiques de niveau recherche, publiés ou non, émanant des établissements d'enseignement et de recherche français ou étrangers, des laboratoires publics ou privés. 


\title{
Lower Abstraction Level of TRIZ Inventive Principles Improves Ideation Productivity of Engineering Students
}

\author{
Pavel Livotov, Arun Prasad Chandra Sekaran, Mas'udah \\ Offenburg University of Applied Sciences, Badstr. 24, 77652 Offenburg, Germany
}

\begin{abstract}
The 40 Altshuller Inventive Principles with numerous sub-principles remain over decades the most frequently applied tool of the Theory of Inventive Problem Solving TRIZ for systematic idea generation. However, their application often requires a concentrated, creative and abstract way of thinking that can be fairly challenging for the newcomers to TRIZ. This paper describes an approach to reduce the abstraction level of inventive sub-principles and presents the results of the idea generation experiment conducted with three groups of undergraduate and graduate students from different years of study in mechanical and process engineering. The students were asked to generate and to record their individual ideas for three design problems using a pre-defined set of classical and modified sub-principles within 10 minutes. The overall outcomes of the experiment support the assumption that the less abstract wording of the modified sub-principles leads to higher number of ideas. The distribution of ideas between the fields of MATCHEM-IBD (Mechanical, Acoustic, Thermal, Chemical, Electrical, Magnetic, Intermolecular, Biological and Data processing) differs significantly between groups using modified and abstract sub-principles.
\end{abstract}

Keywords: TRIZ Inventive Principles, Engineering Creativity, Ideation Performance, Automated Invention.

\section{Introduction}

The theory of inventive problem solving TRIZ developed by Altshuller and his coworkers [1] is considered as one of the most organized and comprehensive methodologies for invention knowledge and creative thinking [2], as confirmed by the analysis of the top cited scientific publications on innovative design [3]. The engineering educators have gathered considerable experience in different education approaches in the systematic innovation with TRIZ [4]. As engineering curricula are tightly packed with subjects and offer little room to TRIZ, it is necessary to successfully embed the TRIZ tools into existing engineering subjects. Recent experiments indicate that effective idea generation with simple TRIZ heuristics of the eight MATCEM-IB fields (Mechanical, Acoustic, Thermal, Chemical, Electric, Magnetic, Intermolecular and Biological) can be successfully taught in just one or two hours [5]. The fast-to-learn ideation technique based on five cross-industry analogies, corresponding to TRIZ feature transfer, function-oriented search, scaling and biomimetics, significantly improves idea generation outcomes 
both in the quantity and variety [6]. Among other TRIZ tools, the 40 Inventive Principles are most frequently used in practice. Inventive Principles are simple to modify for a specific technical domain and can be easily integrated in brainstorming. There are also many proposals of examples illustrating the breadth of application of Altshuller' original 40 Inventive Principles [1] in specific engineering domains, such as electronics, chemical engineering, food processing, ergonomics, maintenance, software engineering etc. 40 Inventive Principles have been updated or extended with new sub-principles in the recent years, as shown for example in [7]. One of the latest updates [8] contains 160 sub-principles with nearly 70 additional sub-principles relevant for process engineering.

However, the application of Inventive Principles often requires simultaneously a concentrated, creative and abstract way of thinking that can be challenging for engineering students or newcomers to TRIZ. For example, the abstract term "object" used in sub-principles may be understood as a system, system component, substance, process or process step, or any other material or virtual object. Also, the abstract definition of "action" can be understood as function, positive or negative effect or any interaction between the objects. Therefore, the outcomes of ideation work with the TRIZ Inventive Principles may depend on a certain interpretation of the abstract terms. Thus, the research goal of the presented study is to analyze how the level of abstractness in formulation of inventive sub-principles can influence the ideation productivity and variety.

The sub-principles can be understood as inventive operators for transformation of technical systems or heuristics for idea generation. In this context, some of the inventive operators are more specific and can be clearly assigned to at least one of the MATCHEIBD fields, where D - is the abbreviature of Data processing or Information field. There is also a group of generally formulated sub-principles, which are independent of any field and hence may have a higher level of abstraction. Thus, the application of fieldoriented (specific) sub-principles and of field-independent (general) sub-principles can have different impact on ideation outcomes. The distribution of the 160 sub-principles [8] over the nine MATCEM-IBD fields is presented in Figure 1.

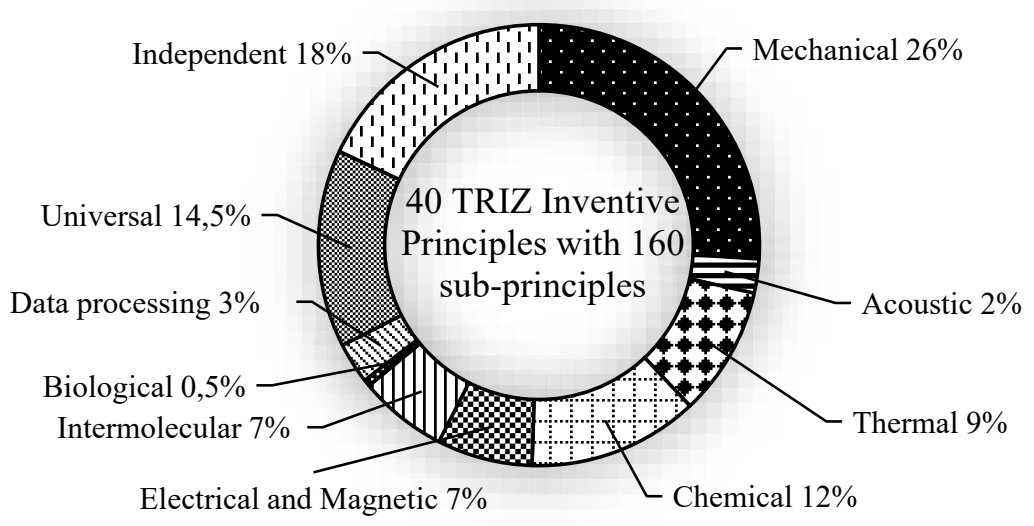

Figure 1. Distribution of the 160 sub-principles over specific MATCEM-IBD fields, field-universal and field-independent categories. 
It can be assumed, that the difficulties in the interpretation of the abstract recommendations in sub-principles can be higher by the application of more abstract fieldindependent sub-principles. In Figure 1 the 160 sub-principles are assigned to 11 categories. The category "Independent" includes 36 sub-principles, which don't relate directly to any field or engineering domain, like for example la) Segment object. The idea generation with these field-independent sub-principles doesn't compulsorily lead to a change of the "field" in the working principle of a technical system. The category "Universal" includes 29 field-universal sub-principles which can be assigned to any of the MATCEM-IBD fields. The remaining 95 sub-principles are distributed with multiple selection between MATCEM-IBD fields.

This paper presents and discusses the results of the experiments that were conducted with the undergraduate and graduate students in mechanical and process engineering in 2019. The in total 194 single experiments engaged students from different years of study in order to establish the correlation of a number and the breadth of ideas proposed with applied ideation techniques. The students were asked to generate solution ideas for three pre-defined problems using in total 15 different sub-principles, i.e. with 5 subprinciples for each problem. The original abstract formulation of sub-principles was offered in 97 experiments, whilst other 97 experiments were carried out with the modified "less abstract", version of the sub-principles. In the modified sub-principles, the abstract terms "object", "action" or "function" were replaced with a context-specific name of a real system component, real function or action in order to reduce the level of abstractness as proposed in [9]. The authors wanted to prove the hypothesis, whether the use of modified inventive principles with less abstract wording helps students in generating more ideas with higher breaths in comparison with application of originally formulated TRIZ Inventive Principles.

\section{Experimental methodology}

Three groups of students from the Offenburg University participated in the experiments. Forty undergraduate students from the group 1 were in their $4^{\text {th }}$ or $5^{\text {th }}$ semester of the Bachelor of Mechanical or Process Engineering Degree. The group 2 contained 23 students enrolled into the Master Degree in Mechanical Engineering (8th and 9th study semesters). The group 3 consisted of 34 undergraduate students that were in their 4th semester in the Bachelor of Mechanical Engineering Degree. All the groups were involved in the experiments at the beginning of the scheduled tutorial classes and were not get acquainted with the TRIZ Inventive Principles beforehand. Experiment participation was voluntary, and the number of participants deviated slightly from one problem to another, as shown in the Table 1 . The groups were supervised by the same tutor.

The groups 1 and 2 participated in idea generation for all three problems within 3 consecutive weeks with one experiment per week. The idea generation forms with the predefined abstract and modified sub-principles were distributed randomly in proportion 50:50. Each student from the groups 1 and 2 has used at least once the idea-generation form with abstract and once with modified sub-principles during the experiments. 
The 34 students of the group 3 were involved in the experiment dealing with last problem only and had no experience in applying TRIZ Inventive Principles before. This control group 3 should help to estimate a possible influence of previous TRIZ experience of groups 1 and 2 on ideation outcomes.

Three problems selected for the experiments are presented in the Table 2. They represent three typical cases of the initial problem situation which can be defined as insufficient positive function (problem 1), elimination of harmful effect (problem 2), and engineering contradiction (problem 3). All problems were introduced to all groups for 3 minutes using one Power Point slide as exemplarily shown in Fig. 2. The slides contained the problem statement and a photo or drawing. All students were given 10 minutes to record as many individual ideas as possible by using recommendations of the five inventive sub-principles, printed on the idea-generation forms. No special explanation of TRIZ Inventive Principles or any introduction how to apply them has been offered to the students. The filled idea-generation forms were evaluated by the authors.

Table 1. Number of students participated in experiments.

\begin{tabular}{|c|c|c|c|c|c|}
\hline \multirow[b]{2}{*}{ Students Group } & \multirow[b]{2}{*}{$\begin{array}{l}\text { Inventive } \\
\text { principles }\end{array}$} & \multicolumn{3}{|c|}{ Number of participants } & \multirow[b]{2}{*}{$\begin{array}{l}\text { Total number of } \\
\text { experiments }\end{array}$} \\
\hline & & $\begin{array}{c}\text { Problem } \\
1 \\
\end{array}$ & $\begin{array}{l}\text { Problem } \\
2 \\
\end{array}$ & $\begin{array}{c}\text { Problem } \\
3 \\
\end{array}$ & \\
\hline \multirow{2}{*}{$\begin{array}{l}\text { 1. Undergraduate } \\
\text { students }\end{array}$} & Abstract & 18 & 15 & 14 & 47 \\
\hline & Modified & 22 & 16 & 9 & 47 \\
\hline \multirow{2}{*}{ 2. Graduate students } & Abstract & 12 & 11 & 10 & 33 \\
\hline & Modified & 11 & 12 & 10 & 33 \\
\hline \multirow{2}{*}{$\begin{array}{l}\text { 3. Control group (un- } \\
\text { dergraduate students) }\end{array}$} & Abstract & - & - & 17 & 17 \\
\hline & Modified & - & - & 17 & 17 \\
\hline \multirow{2}{*}{ All groups } & Abstract & 30 & 26 & 41 & 97 \\
\hline & Modified & 33 & 28 & 36 & 97 \\
\hline
\end{tabular}

Table 2. Problems used in the experiments.

\begin{tabular}{|l|l|l|l|}
\hline \multicolumn{1}{|c|}{ Problem } & \multicolumn{1}{|c|}{ Description } & \multicolumn{1}{|c|}{$\begin{array}{c}\text { Initial } \\
\text { problem field }\end{array}$} & $\begin{array}{c}\text { Problem } \\
\text { type }\end{array}$ \\
\hline $\begin{array}{l}\text { 1. Ship hull } \\
\text { cleaning }\end{array}$ & $\begin{array}{l}\text { How to intensify the hull cleaning of } \\
\text { big ships from maritime organisms } \\
\text { (alga and shell layers) with high-pres- } \\
\text { sure water jetting without paint layer } \\
\text { damage? }\end{array}$ & $\begin{array}{l}\text { Biological, } \\
\text { Intermolecular, } \\
\text { Mechanical }\end{array}$ & $\begin{array}{l}\text { Insufficient } \\
\text { positive } \\
\text { function }\end{array}$ \\
\hline $\begin{array}{l}\text { 2. Removing } \\
\text { lime build-up } \\
\text { in pipes }\end{array}$ & $\begin{array}{l}\text { Calcium carbonate, or lime, is a hard } \\
\text { deposit found in the inner surface of } \\
\text { pipes and other surfaces. How to re- } \\
\text { move the lime build up in pipes? }\end{array}$ & $\begin{array}{l}\text { Chemical, } \\
\text { Intermolecular, } \\
\text { Mechanical }\end{array}$ & $\begin{array}{l}\text { Elimination } \\
\text { of harmful } \\
\text { effect }\end{array}$ \\
\hline $\begin{array}{l}\text { 3. Roadway } \\
\text { condition } \\
\text { monitoring }\end{array}$ & $\begin{array}{l}\text { A camera (sensor) for detection of } \\
\text { roadway condition is placed in a vehi- } \\
\text { cle close to the road surface to detect } \\
\text { its properties: dry, wet, dirty, icy etc. }\end{array}$ & $\begin{array}{l}\text { Electromagnetic } \\
\text { (optical), } \\
\text { Mechanical, } \\
\text { Data } \\
\text { processing }\end{array}$ & $\begin{array}{l}\text { Engineering } \\
\text { contradic- } \\
\text { tion }\end{array}$ \\
\hline $\begin{array}{l}\text { How to protect the sensor from getting } \\
\text { of road monitoring? }\end{array}$ & \\
\hline
\end{tabular}




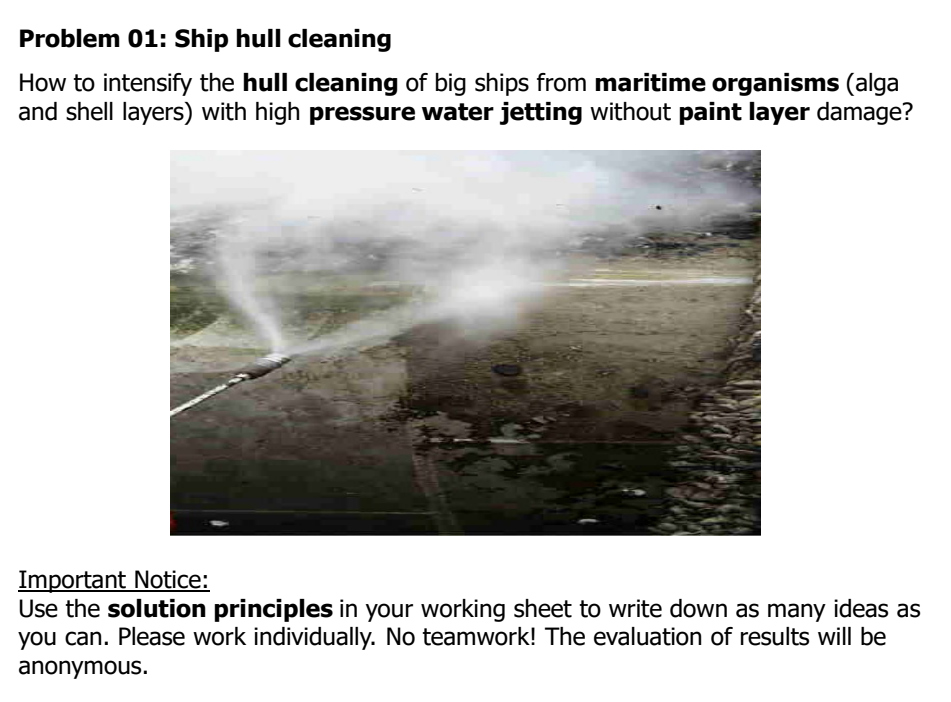

Figure 2. The Power Point slide of the problem statement 1 presented to the students.

For each problem the idea generation was supported by five inventive sub-principles corresponding to 7 statistically strongest TRIZ Inventive Principles as shown in the Table 3. All sub-principles pre-defined for idea generation in the problems 1 and 2 can be assigned to the engineering fields MATCEM-IBD, as well as the sub-principle $15 \mathrm{~d}$ ) Flexible Elements in the Problem 3. On the contrary, the four selected sub-principles in the problem 3, such as 1a) Segment object, 3c) Different functions, 10a) Prior useful function and 19a) Periodic action, are field-independent, i.e. don't relate directly to any field or engineering domain.

Table 3. TRIZ Inventive Principles and sub-principles used in the experiments.

\begin{tabular}{|c|l|l|}
\hline \multicolumn{1}{|c|}{ Problem } & $\begin{array}{c}\text { Recommended TRIZ inventive principles } \\
\text { (IP) and sub-principles }\end{array}$ & $\begin{array}{l}\text { Corresponding fields } \\
\text { MATCEM-IBD }\end{array}$ \\
\hline 1. Ship hull cleaning & $\begin{array}{l}\text { IP35. Transformation of the physical and } \\
\text { chemical properties: } \\
\text { sub-principles 35a, 35b, 35c, 35d, 35e }\end{array}$ & M-T-C-E-M-I \\
\hline $\begin{array}{l}\text { 2. Removing lime } \\
\text { build-up in pipes }\end{array}$ & $\begin{array}{l}\text { IP28. Replacement of mechanical working } \\
\text { principle: } \\
\text { sub-principles 28a, 28b, 28e, 28d, 28e }\end{array}$ & A-T-C-E-M-B \\
\hline $\begin{array}{l}\text { 3. Roadway condi- } \\
\text { tion monitoring }\end{array}$ & $\begin{array}{l}\text { IP1. Segmentation: sub-principle 1a } \\
\text { IP3. Local Quality: sub-principle 3c } \\
\text { IP10. Prior useful action: sub-principle 10a }\end{array}$ & $\begin{array}{l}\text { field-independent } \\
\text { field-independent } \\
\text { field-independent } \\
\text { IP (mechanical) } \\
\text { IP19. Dynamism: sub-principle 15d }\end{array}$ \\
\hline
\end{tabular}

The examples of the abstract and modified sub-principles in the idea-generation forms are presented in the Table 4 . The exact wording of all abstract and modified subprinciples for the problems 1,2 and 3 is enclosed in the Appendix. 
Table 4. Examples of the abstract and modified sub-principles in the idea-generation forms.

\begin{tabular}{|l|l|}
\hline \multicolumn{1}{|c|}{ Abstract inventive sub-principle } & \multicolumn{1}{c|}{ Modified inventive sub-principle } \\
\hline Example of sub-principle 35a applied for problem 1 \\
\hline $\begin{array}{l}\text { 35a) Change an object's aggregate state: e.g. } \\
\text { solid to liquid or liquid to gas - or vice versa. }\end{array}$ & $\begin{array}{l}\text { 35a) Change the aggregate state of the water } \\
\text { jet or maritime organism e.g. solid to liquid } \\
\text { or liquid to gas - or vice versa. }\end{array}$ \\
\hline Example of sub-principle 28c applied for problem 2 \\
\hline $\begin{array}{l}\text { 28c) Use an acoustic working principle, for ex- } \\
\text { ample, sound, ultrasonic or infrasonic oscilla- } \\
\text { tions, cavitation. }\end{array}$ & $\begin{array}{l}\text { 28c) Use an acoustic working principle to } \\
\text { remove lime build up. for ex., sound, ultra- } \\
\text { sonic or infrasonic oscillations, cavitation. }\end{array}$ \\
\hline Example of sub-principle 1a applied for problem 3 \\
\hline $\begin{array}{l}\text { 1a) Segment object: divide the objects into in- } \\
\text { dependent objects or parts. }\end{array}$ & $\begin{array}{l}\text { 1a) Segment object: divide the sensor into } \\
\text { independent sensors or parts. }\end{array}$ \\
\hline
\end{tabular}

Among the major metrics for objective assessment of ideation effectiveness, such as ideas quantity, variety, and quality [10], the quantity and variety of independent ideas proposed with abstract and modified inventive sub-principles were evaluated in the experiments. The assessment of the ideas quality and novelty was not a part of this study. It was also difficult to judge about the quality of ideas developed by the students as the ideation time of 10 minutes in total was too short for detailed design or feasibility check.

\section{$3 \quad$ Results and Discussion}

\subsection{Quantity of Generated Ideas}

The quantitative analysis of 902 ideas generated by students in 194 experiments is summarized in the Table 5. It undoubtedly shows that the number of ideas generated with modified sub-principles exceeded the number of ideas generated with abstract sub-principles in all groups and for all problems. On average students proposed 1.53 times more ideas with the less abstract sub-principles (5.63 versus 3.67 ideas per person).

Table 5. Quantity of ideas generated by different students' groups.

\begin{tabular}{|c|c|c|c|c|c|c|c|}
\hline \multirow{2}{*}{$\begin{array}{c}\text { Students' } \\
\text { Group }\end{array}$} & \multirow[b]{2}{*}{$\begin{array}{l}\text { Inventive } \\
\text { principles }\end{array}$} & \multicolumn{6}{|c|}{ Number of ideas / mean number of ideas per person } \\
\hline & & $\begin{array}{c}\text { Problem } \\
1 \\
\end{array}$ & $\begin{array}{c}\text { Problem } \\
2 \\
\end{array}$ & $\begin{array}{c}\text { Problem } \\
3 \\
\end{array}$ & $\begin{array}{c}\text { Total } \\
\text { number }\end{array}$ & $\begin{array}{l}\text { Total } \\
\text { Mean }\end{array}$ & $\begin{array}{c}\text { Total } \\
\text { SD }\end{array}$ \\
\hline \multirow{2}{*}{$\begin{array}{l}\text { 1. Under } \\
\text { graduate }\end{array}$} & Modified & 131 & 89 & 46 & 266 & 5.66 & 2.06 \\
\hline & Abstract & 59 & 54 & 62 & 175 & 3.72 & 1.78 \\
\hline \multirow{2}{*}{ 2. Graduate } & Modified & 77 & 71 & 49 & 197 & 5.97 & 2.42 \\
\hline & Abstract & 52 & 44 & 31 & 127 & 3.85 & 1.44 \\
\hline \multirow{2}{*}{ 3. Control } & Modified & - & - & 83 & 83 & 4.88 & 2.81 \\
\hline & Abstract & - & - & 54 & 54 & 3.18 & 1.34 \\
\hline \multirow{2}{*}{ All groups } & Modified & 208 & 160 & 178 & 546 & 5.63 & 2.36 \\
\hline & Abstract & 111 & 98 & 147 & 356 & 3.67 & 1.62 \\
\hline
\end{tabular}

Although, the average number of ideas generated by a graduate student in the group 2 exceeded the number of ideas generated by an undergraduate student in the group 1 
(5.97 versus 5.66 for modified sub-principles and 3.85 versus 3.72 for abstract principles), this difference was not statistically significant. Nevertheless, the graduate students were able to describe their ideas more precisely and as a rule on a higher qualitative level.

The gain in ideation productivity by using modified sub-principles can be defined as a quotient of number of ideas generated with modified and abstract sub-principles:

where:

$$
g=\frac{N_{\text {mod }}}{N_{\text {abst }}}
$$

$N_{\text {mod }} \quad$ : number of ideas per person generated with modified inventive principles

$N_{a b s t} \quad$ : number of ideas per person generated with abstract inventive principles.

As documented in the Table 5, the gain in ideation productivity remains almost constant over all student groups with $g=1.52$ (group 1), $g=1.55$ (group 2) and $g=1.53$ (group 3 ). At the same time, Figure 3 shows uneven ideation performance over the problems, both in number of ideas per person and in gain of ideation productivity with modified inventive sub-principles. Interestingly, that the average number of ideas per person, generated with abstract sub-principles remains almost constant and varies between 3.59 and 3.77 within the range of $\pm 2.4 \%$. Consequently, one cannot explain these results simply with different complexity level of the problems, even if it's thinkable that the problem 3 "Roadway condition monitoring", formulated in form of engineering contradiction, could appear to be more difficult for the students.

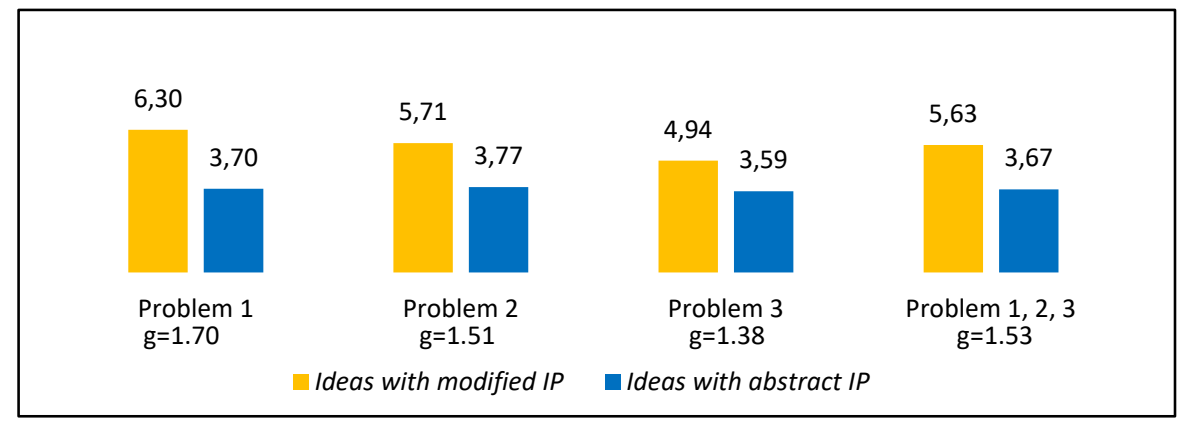

Figure 3. Ideas generated by students for different problems (ideas per person, mean values).

Another reason for a relative lower number of ideas per person generated with modified inventive principles for the problem 3 could be the fact that 4 from 5 proposed sub-principles (1a, 3c, 10a, 19a; see Table 3 ) belong to the category of more abstract field-independent sub-principles. With the help of these four sub-principles the students proposed on average 0.81 ideas per person with modified wording and 0.54 ideas per person with abstract formulation. The average number of ideas per person generated with other 11 field-oriented sub-principles (35a, 35b, 35c, 35d, 35e, 28a, 28b, 28c, 28d, $28 \mathrm{e}, 15 \mathrm{~d}$ ) in all experiments was 1.21 for modified and 0.83 for abstract sub-principles respectively. 
Moreover, it is worth to note that the application of inventive sub-principles as separate heuristics both in abstract and modified form allowed to reach a higher discipline of idea generation as the directions of thinking were clearly pre-defined by the subprinciples. Thus, from 546 ideas formulated with modified sub-principles only 29 ideas $(5.3 \%)$ could not be assigned to the recommended sub-principles. From 356 ideas formulated with abstract sub-principles solely 18 ideas (5.1\%) are not related to any recommended sub-principle.

The distribution of ideas per person over the number of all experiments is shown in Figure 4. It illustrates that the application of modified sub-principles increases the number of students with higher personal ideation output. For example, using modified subprinciples the students could generate between 7 and 8 ideas per person in 25 experiments from 97 . On the contrary, the students working with the abstract sub-principles proposed $7 \ldots 8$ ideas per person in only 4 experiments from 97 .

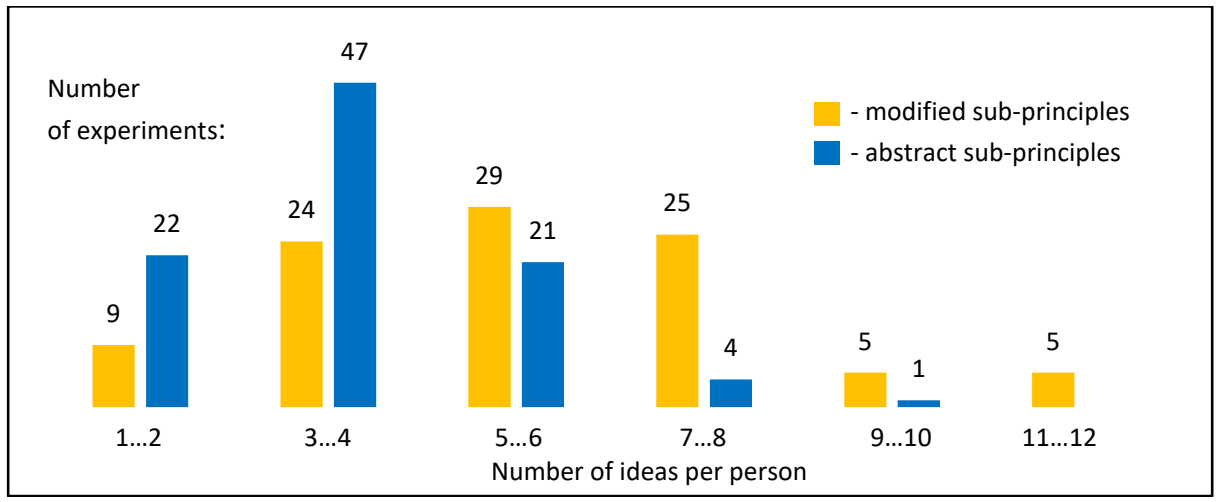

Figure 4. Distribution of number of ideas per person over all experiments.

Finally, the comparison of the ideation outcomes of all student groups 1, 2 and 3 for the problem 3 "Roadway condition monitoring" is presented in the Table 6. Although the 34 undergraduate students of the control group 3 participated in the idea generation for the problem 3 only, their ideation productivity does not significantly differ from the outcomes of the undergraduate students (group 1) and graduate students (group 2), who have already gained some experience in applying TRIZ inventive principles for the problems 1 and 2 .

Table 6. Quantity of ideas generated by different students' groups for the problem 3.

\begin{tabular}{|l|c|c|c|c|}
\hline \multirow{2}{*}{ Students' Group } & \multirow{2}{*}{$\begin{array}{c}\text { Inventive sub- } \\
\text { principles }\end{array}$} & \multicolumn{2}{|c|}{ Problem 3. Roadway condition monitoring } \\
\cline { 3 - 4 } & Number of ideas per person & SD & $g=\mathrm{N}_{\text {mog }} / \mathrm{N}_{\text {abst }}$ \\
\hline \multirow{2}{*}{ 1. Undergraduate } & Modified & 5.11 & 1.91 & \multirow{2}{*}{$g=1.15$} \\
\cline { 2 - 4 } & Abstract & 4.43 & 1.93 & \\
\hline \multirow{2}{*}{ 2. Graduate } & Modified & 4.90 & 1.92 & \multirow{2}{*}{$g=1.58$} \\
\cline { 2 - 4 } & Abstract & 3.10 & 1.64 & \multirow{2}{*}{$g=1.54$} \\
\hline \multirow{2}{*}{$\begin{array}{c}\text { 3. Undergraduate } \\
\text { (Control group) }\end{array}$} & Modified & 4.88 & 2.81 & 1.34 \\
\cline { 2 - 4 } & Abstract & 3.18 & \multicolumn{2}{|c}{} \\
\hline
\end{tabular}


The following are some outcomes of the Mann-Whitney test that was used for the statistical comparison of responses in the experiments. With $Z=-4.38$ and $p<0.01$ the 47 undergraduate students from the group 1 generated for the problems 1,2 and 3 on average significantly more ideas with the modified inventive sub-principles than with the classical more abstract sub-principles. With $Z=-3.62$ and $p<0.01$ the 33 graduate students from the group 2 generated more ideas with the modified sub-principles for all three problems as well. And finally, 17 undergraduate students from the control group 3 proposed for the problem 3 with $Z=-1.98$ and $p<0.05$ significantly more ideas with the modified sub-principles as well.

\subsection{Breadth or Variety of Generated Ideas}

In order to assess the variety of the ideas proposed in the experiments, the ideas generated in each group were assigned to the most appropriate knowledge domains or fields, using the MATCEMIBD classification. The distribution of different ideas over the nine MATCEMIBD categories in all groups is illustrated in Figure 5. The students from all groups proposed significantly broader ideas using the modified inventive subprinciples. Substantial differences of the gain in ideation productivity $g>1,5$ are observed for Acoustic, Thermal, Biological fields and especially for Data processing with $g=3,56$.

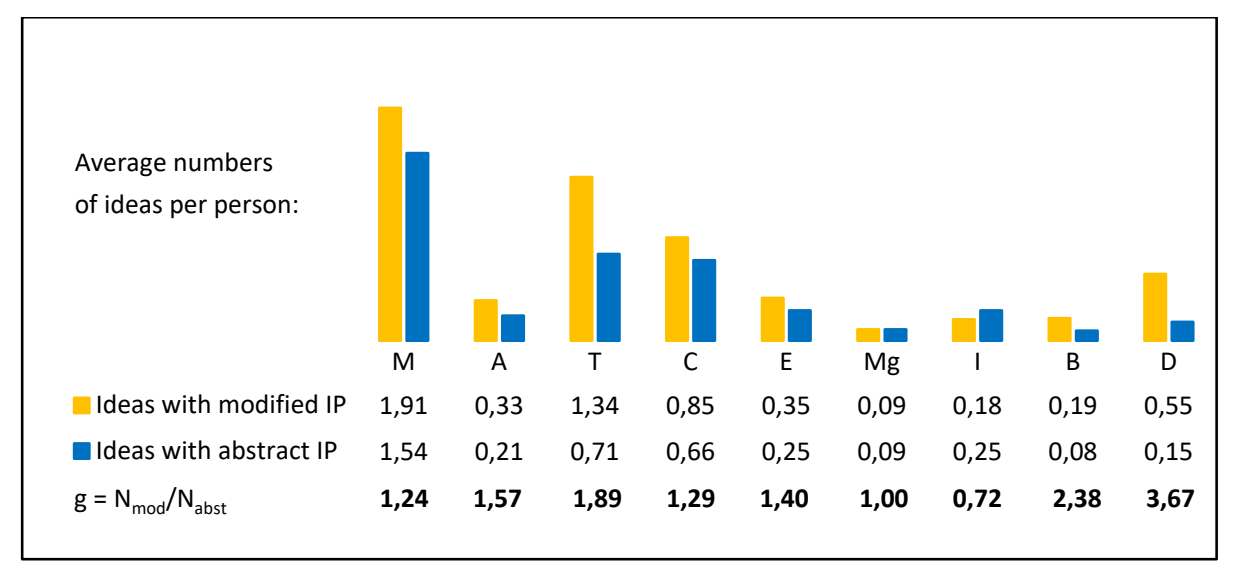

Figure 5. Variety of different ideas and their distribution over MATCEMIBD categories.

The students from the groups 1, 2 and 3 while using the modified sub-principles, proposed $67 \%$ of non-mechanical ideas which can be assigned to the fields ATCEMIBD. On the contrary, only $58 \%$ of ideas generated by all students using the classical abstract sub-principles, can be assigned to these non-mechanical fields. 


\section{Concluding Remarks}

The overall results of the study support the assumption that the less abstract and problem specific formulation of TRIZ Inventive Principles can visibly improve idea generation outcomes of engineering students and newcomers to TRIZ both in the quantity and variety of proposed ideas. In 194 experiments conducted at the Offenburg University the students generated nearly 1.5 more ideas with the modified inventive subprinciples. Also, the breadth of the proposed ideas over the nine MATCEMIBD fields has been essentially enhanced. However, it wasn't found that the differences in the knowledge level of the students from different years of study have a significant effect on their ideation performance with the modified or abstract inventive principles. This statement can be the subject matter of a future research. Based on the outcomes of the study, the authors recommend the proposed approach to be taken into consideration by the educators and practitioners in creativity and innovation with TRIZ methodology. The authors advocate the idea that the adaptation of Inventive Principles for specific tasks will make it considerably easier for newcomers and companies to apply TRIZ in engineering work. Most modifications in inventive sub-principles can be made automatically and the development such algorithms is the subject of the current research.

\section{References}

1. Altshuller, G.S.: Creativity as an exact science. The theory of the solution of inventive problems. Gordon \& Breach Science Publishers, ISSN 0275-5807, London (1984).

2. Cavallucci, D., Cascini, G., Duflou, J., et al.: TRIZ and Knowledge-Based Innovation in Science and Industry. Procedia Eng. 131 (2015), 1-2. doi:10.1016/j.proeng.2015.12.341.

3. Chechurin, L., Borgianni, Y.: Understanding TRIZ through the review of top cited publications. Computers in Industry, Volume 82 (2016), 119-134, https://doi.org/10.1016/j.compind.2016.06.002.

4. Belski, I., Cavallucci, D., Hentschel, C., et al.: Sustainable Education in Inventive Problem Solving with TRIZ and Knowledge-Based Innovation at Universities. In: Cavallucci, D., de Guio, R., Koziołek S. (Eds.), Automated Invention for Smart Industries, IFIP Advances in Information and Communication Technology, Vol. 541, Springer, Cham, pp.51-74 (2018).

5. Belski, I., Livotov, P., Mayer, O.: Eight Fields of MATCEMIB Help Students to Generate More Ideas. Proc. CIRP, Vol. 39, Pages 85-90 (2016).

6. Livotov, P.: Enhancing Innovation and Entrepreneurial Competences of Engineering Students through a Systematic Cross-Industry Innovation Learning Course. Proceedings of the 29th Annual Conference of the Australasian Association for Engineering Education (AAEE), 9.-12.12.2018, Hamilton, New Zealand (2018).

7. Petrov, V.: Universal Inventive Principles TRIZ: Inventive principles for all fields. Kindle Edition, ASIN: B07CRRY99N, 226 p., (2018).

8. Livotov, P., Chandra Sekaran, A.P., Law, R., Mas'udah, Reay, D.: Systematic Innovation in Process Engineering: Linking TRIZ and Process Intensification. In: Chechurin L., Collan M., Advances in Systematic Creativity, Palgrave Macmillan, p. 27-44 (2019).

9. TRIZ Trainingsbuch: Systematische Produktentwicklung und erfinderische Problemlösung mit TRIZ Methodik (Selbstlernkurs). TriS Europe Berlin, 88 p. (2012).

10. Shah, J. J., Vargas-Hernandez, N., Smith, S. M.: Metrics for measuring ideation effectiveness. Design Studies, 24(2), 111-134. DOI: 10.1016/S0142-694X(02)00034-0, (2003). 
Appendix: Abstract and modified inventive sub-principles applied in experiments.

\begin{tabular}{|c|c|c|}
\hline $\mathbf{N}$ & Abstract sub-principles [8] & Modified sub-principles \\
\hline \multicolumn{3}{|c|}{ Problem 1: Ship hull cleaning } \\
\hline $35 \mathrm{a}$ & $\begin{array}{l}\text { Change an object's aggregate state: e.g. } \\
\text { solid to liquid or liquid to gas - or vice } \\
\text { versa. }\end{array}$ & $\begin{array}{l}\text { Change the aggregate state of the water jet or } \\
\text { maritime organism e.g. solid to liquid or liq- } \\
\text { uid to gas - or vice versa. }\end{array}$ \\
\hline $35 b$ & $\begin{array}{l}\text { Change the object's concentration or con- } \\
\text { sistency. }\end{array}$ & $\begin{array}{l}\text { Change the concentration or consistency of } \\
\text { the water jet or maritime organisms. }\end{array}$ \\
\hline $35 c$ & $\begin{array}{l}\text { Change the object's physical properties: } \\
\text { pressure, density, hardness, viscosity, } \\
\text { conductivity, magnetism etc. }\end{array}$ & $\begin{array}{l}\text { Change physical properties of the water jet or } \\
\text { maritime organisms e.g. pressure, density, } \\
\text { hardness, viscosity, conductivity, magnetism } \\
\text { etc. }\end{array}$ \\
\hline $35 \mathrm{~d}$ & Chang & $\begin{array}{l}\text { Change the temperature of the water jet or } \\
\text { maritime organisms }\end{array}$ \\
\hline $35 \mathrm{e}$ & $\begin{array}{l}\text { Change other chemical properties: for- } \\
\text { mulation, } \mathrm{pH} \text {, solubility etc. Change pro- } \\
\text { cess chemistry. }\end{array}$ & $\begin{array}{l}\text { Change other chemical properties of the wa- } \\
\text { ter jet or maritime organism formulation, } \mathrm{pH} \text {, } \\
\text { solubility etc. Change process chemistry. }\end{array}$ \\
\hline \multicolumn{3}{|c|}{ Problem 2: Removing lime build-up in pipes } \\
\hline $28 \mathrm{a}$ & $\begin{array}{l}\text { Replace the mechanical working princi- } \\
\text { ple by electric, magnetic, or electromag- } \\
\text { netic one. Use electric, magnetic or elec- } \\
\text { tromagnetic effect on the object. }\end{array}$ & $\begin{array}{l}\text { hanical working principle } \\
\text { hetic or electromagnetic } \\
\text { magnetic or electromag- } \\
\text { me build up or pipe. }\end{array}$ \\
\hline $28 \mathrm{~b}$ & $\begin{array}{l}\text { Use optic } \\
\text { ple, infra }\end{array}$ & $\begin{array}{l}\text { remove } \\
\text { ared, ultravi- }\end{array}$ \\
\hline $28 \mathrm{c}$ & $\begin{array}{l}\text { For } \\
\text { sonic }\end{array}$ & $\begin{array}{l}\text { ing principle to remove } \\
\text { ample, sound, ultra- } \\
\text { cillations, cavitation. }\end{array}$ \\
\hline $28 \mathrm{~d}$ & $\begin{array}{l}\text { rex- } \\
\text { xpan- }\end{array}$ & $\begin{array}{l}\text { Use } \\
\text { pipe } \\
\text { expa }\end{array}$ \\
\hline $28 \mathrm{e}$ & $\begin{array}{l}\text { Use chemical or biological working prin- } \\
\text { ciple. For example, chemical reactions } \\
\text { (dissolution synthesis) or bio-organisms } \\
\text { (microbes, enzymes). }\end{array}$ & $\begin{array}{l}\text { Use chemical or biological working principle } \\
\text { to remove lime build up. For example, chem- } \\
\text { ical reactions (dissolution, synthesis) or bio- } \\
\text { organisms (microbes, enzymes). }\end{array}$ \\
\hline \multicolumn{3}{|c|}{ Problem 3: Roadway condition monitoring } \\
\hline $1 \mathrm{a}$ & $\begin{array}{l}\text { Segment object: divide the objects into } \\
\text { independent objects or parts. }\end{array}$ & $\begin{array}{l}\text { Segr } \\
\text { pena }\end{array}$ \\
\hline $3 \mathrm{c}$ & $\begin{array}{l}\text { Different fun } \\
\text { the object sl } \\
\text { tions }\end{array}$ & $\begin{array}{l}\text { arts of the } \\
\text { nitoring }\end{array}$ \\
\hline $10 \mathrm{a}$ & $\begin{array}{l}\text { Prior useful function: perform the re- } \\
\text { quired action or useful function in ad- } \\
\text { vance, either fully or partially. }\end{array}$ & $\begin{array}{l}\text { Prior useful function: perform the road mon- } \\
\text { itoring in advance, either fully or partially. }\end{array}$ \\
\hline $15 \mathrm{~d}$ & $\begin{array}{l}\text { Flexible elements: use adaptive and flex- } \\
\text { ible elements like joints, springs, elasto- } \\
\text { mers, fluids, gases. }\end{array}$ & $\begin{array}{l}\text { Flexible elements: protect the sensor by us- } \\
\text { ing adaptive and flexible elements like } \\
\text { joints, springs, elastomers, fluids, gases. }\end{array}$ \\
\hline $19 \mathrm{a}$ & $\begin{array}{l}\text { Periodic action: replace a continuous ac- } \\
\text { tion with a periodic or pulsed one. }\end{array}$ & $\begin{array}{l}\text { Periodic action: replace a continuous road } \\
\text { monitoring with a periodic or pulsed one. }\end{array}$ \\
\hline
\end{tabular}

